\title{
LA-ICP-MS U-Pb Dating of Cenozoic Rutile Inclusions in the Yuanjiang Marble-Hosted Ruby Deposit, Ailao Shan Complex, Southwest China
}

\author{
Tianjian Yang ${ }^{1,2}$, Xiaoming Sun ${ }^{1,3,4, *} \mathbb{C}$, Guiyong Shi ${ }^{3,4}$ and Ying Liu ${ }^{3,4}$ \\ 1 School of Earth Sciences and Engineering, Sun Yat-sen University, Guangzhou 510275, China; \\ yangtianjian@scies.org \\ 2 South China Institute of Environmental Sciences, The Ministry of Ecology and Environment of China, \\ Guangzhou 510655, China \\ 3 Guangdong Provincial Key Laboratory of Marine Resources and Coastal Engineering, Guangzhou 510275, \\ China; eessgy@mail.sysu.edu.cn (G.S.); liuy476@mail.sysu.edu.cn (Y.L.) \\ 4 School of Marine Sciences, Sun Yat-sen University, Guangzhou 510006, China \\ * Correspondence: eessxm@mail.sysu.edu.cn; Tel.: +86-0756-3668827
}

check for updates

Citation: Yang, T.; Sun, X.; Shi, G.; Liu, Y. LA-ICP-MS U-Pb Dating of Cenozoic Rutile Inclusions in the Yuanjiang Marble-Hosted Ruby Deposit, Ailao Shan Complex, Southwest China. Minerals 2021, 11, 433. https://doi.org/10.3390/ $\min 11040433$

Academic Editor: Frederick Lin Sutherland

Received: 23 March 2021

Accepted: 15 April 2021

Published: 19 April 2021

Publisher's Note: MDPI stays neutral with regard to jurisdictional claims in published maps and institutional affiliations.

Copyright: (c) 2021 by the authors. Licensee MDPI, Basel, Switzerland. This article is an open access article distributed under the terms and conditions of the Creative Commons Attribution (CC BY) license (https:/ / creativecommons.org/licenses/by/ $4.0 /)$.

\begin{abstract}
Among the marble-hosted ruby deposits in the Himalayan tectonic belt, which yields the highest-quality rubies in the world, the Yuanjiang deposit is the only economically viable one located in China. More attempts are necessary to put constraints on the ore-forming age of these marble-hosted ruby deposits. Here, we dated rutile inclusions in the Yuanjiang rubies using the LA-ICP-MS U-Pb method, which yielded a lower intercept ${ }^{206} \mathrm{~Pb} /{ }^{238} \mathrm{U}$ age of $20.2 \pm 1.2 \mathrm{Ma}$ on the Tera-Wasserburg plot, close to the 22.5-22.2 Ma ${ }^{40} \mathrm{Ar} /{ }^{39} \mathrm{Ar}$ ages of phlogopite from the ruby host matrix assemblage. Our $\mathrm{U}-\mathrm{Pb}$ rutile age put a constraint on the cooling history of the Yuanjiang rubies deposit. The new rutile age is consistent with our previous model that shows the ca. 28-22 Ma left lateral shearing plays an important role in transporting the ruby deposit toward the surface. This study provides the first example of in-situ $\mathrm{U}-\mathrm{Pb}$ dating of rutile in the Himalayan tectonic belt, demonstrating the great potential of $\mathrm{U}-\mathrm{Pb}$ rutile geochronology for Cenozoic mineral deposits.
\end{abstract}

Keywords: Cenozoic rutile U-Pb dating; marble-hosted ruby deposit; Ailao Shan Complex

\section{Introduction}

The marble-hosted ruby deposits in Central and Southeast Asia produce rubies of the highest quality [1]. Characterized by deep-red color and high transparency, these ruby deposits were developed during the Cenozoic India-Eurasia continental collision and outcrop in sutures or extrusion shearing zones (Figure 1A, [1,2]). The Yuanjiang marblehosted ruby deposit in the Ailao Shan Complex is the only economic ruby deposit in China up to now $[3,4]$.

The simple formula $\mathrm{Al}_{2} \mathrm{O}_{3}$ of ruby carries limited geochronological information, which is a premise to understand the relationship between ruby mineralization and tectonic evolution. Only limited geochronological tools have been used to date the ore-forming age of the ruby deposit, such as ${ }^{40} \mathrm{Ar}-{ }^{39} \mathrm{Ar}$ dating of micas from the ruby host matrix assemblage and $\mathrm{U}-\mathrm{Pb}$ dating of zircon inclusions in rubies. For the Yuanjiang ruby deposit, a previous study obtained the ${ }^{40} \mathrm{Ar}-{ }^{39} \mathrm{Ar}$ ages of phlogopites and $\mathrm{U}-\mathrm{Pb}$ age of zircon inclusions, which are 22.5-22.2 Ma and 36.2 Ma, respectively [5]. However, the closure temperature of micas ${ }^{40} \mathrm{Ar}-{ }^{39} \mathrm{Ar}$ system $\left(425^{\circ} \mathrm{C}\right.$, [6]) is significantly lower than the marblehosted ruby formation temperature $\left(610-790^{\circ} \mathrm{C},[1]\right)$, and integrating with the fact that micas can be easily overprinted by later tectonic disturbance often render the interpretations of mica ${ }^{40} \mathrm{Ar}-{ }^{39} \mathrm{Ar}$ ages ambiguous [7]. The U-Pb system closure temperature of zircon is close to ruby formation, and zircon inclusions are protected by hosted rubies from later interaction of permeating fluids and $\mathrm{U}-\mathrm{Pb}$ resetting, making zircon inclusions as 
potential candidates for constraining the crystallization age of gem ruby and sapphire deposits [1,5,8-12]. However, the potential residual of inherited cores may result in mixed, even meaningless ages, considering that the analytical spots are usually more than $20 \mu \mathrm{m}$ in LA-ICP-MS or SIMS analyses [13]. Therefore, to better define the ore-forming age of the marble-hosted ruby deposits, geochronological constraints from other minerals syngenetic to rubies are warranted.

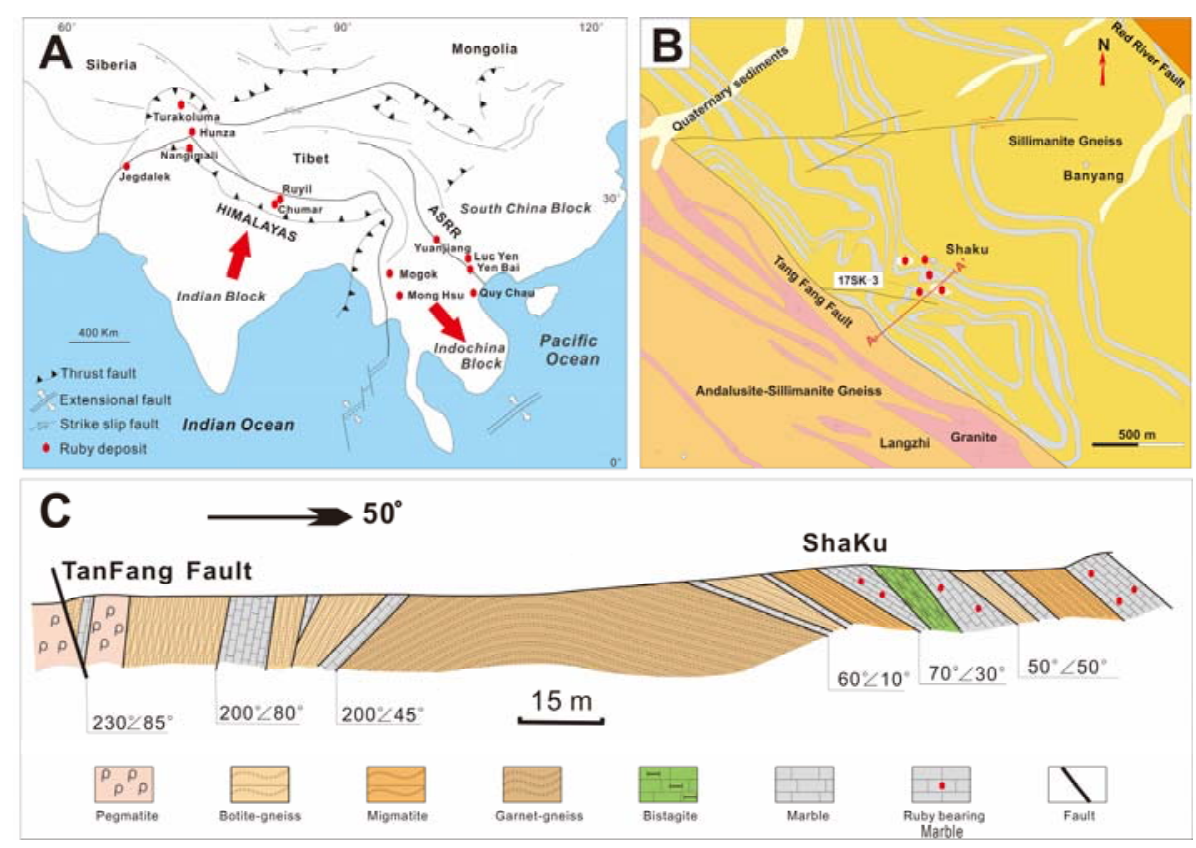

Figure 1. (A) Outcrop of marble-hosted ruby deposits in Central and Southeast Asia (modified after [1]). (B) Geological map of the Yuanjiang marble-hosted ruby deposit (modified after [5]). (C) The cross-section profile map of Shaku anticline (Its location corresponds to $A-\mathrm{A}^{\prime}$ in Figure $1 \mathrm{~B}$ ).

Rutile, another common mineral inclusion in the Central and Southeast Asia marblehosted rubies [1], is potentially suitable candidate for $\mathrm{U}-\mathrm{Pb}$ dating if sufficient $\mathrm{U}$ was incorporated [14]. In contrast to the ambiguous interpretation of $\mathrm{U}-\mathrm{Pb}$ age of zircon (e.g., inherited, metamorphic or even mixed ages), the $\mathrm{U}-\mathrm{Pb}$ age of rutile records the latest cooling age to the $\mathrm{Pb}$ diffusion closure temperature of rutile as the result of faster $\mathrm{Pb}$ diffusion rate [13-16]. Therefore, dating the rutile inclusions has the potential to provide new constraint on the ore-forming age of ruby deposits that can be compared with geochronology produced by other methods. LA-ICP-MS U-Pb dating of rutile inclusions in corundum (ruby and sapphire) was firstly reported by [13], defining a minimum age of 499-533 Ma for corundum growth in the Mozambique belt.

Here, we present compositional and chronological data of rutile inclusions in rubies from the Yuanjiang marble-hosted ruby deposit, which set an example of dating Cenozoic rutile. Coupled with the previously obtained $\mathrm{U}-\mathrm{Pb}$ zircon inclusion age and ${ }^{40} \mathrm{Ar} /{ }^{39} \mathrm{Ar}$ phlogopite ages, the genetic link between ruby mineralization and tectonic evolution in the Ailao Shan-Red River shear zone was further discussed in the Section 5.3.

\section{Geological Setting}

As one of the marble-hosted ruby deposits in Central and Southeast Asia, the Yuanjiang ruby deposit is located in the middle of the Ailao Shan Complex, the longest part of Ailao Shan-Red River shear zone (ASRR, Figure 1A, [1]). The Yuanjiang ruby deposit outcrops in the NE limb of Shaku anticline and is trapped between the Tangfang Fault and the Red River Fault (Figure 1B,C). In general, the mineral assemblage of the Yuanjiang ruby deposits is very similar to that of other ruby deposits in Central and Southeast 
Asia $[1,5]$. The detailed regional and ore geological setting has been described in our previous paper [5].

\section{Materials and Methods}

Ruby-bearing marble samples are collected from three layers of orebody at the Shaku village $\left(102^{\circ} 05^{\prime} 31.41^{\prime \prime} \mathrm{E}, 23^{\circ} 27^{\prime} 52.03^{\prime \prime} \mathrm{N}\right)$. Rubies are found as spotted crystals in coarsegrained marble or associated with phlogopite, graphite and pyrite in foliations [5]. Rutile inclusions are identified in the hosted ruby crystals under microscope transmitted light by the characters of high relief and dark-brown color (Figure 2A).
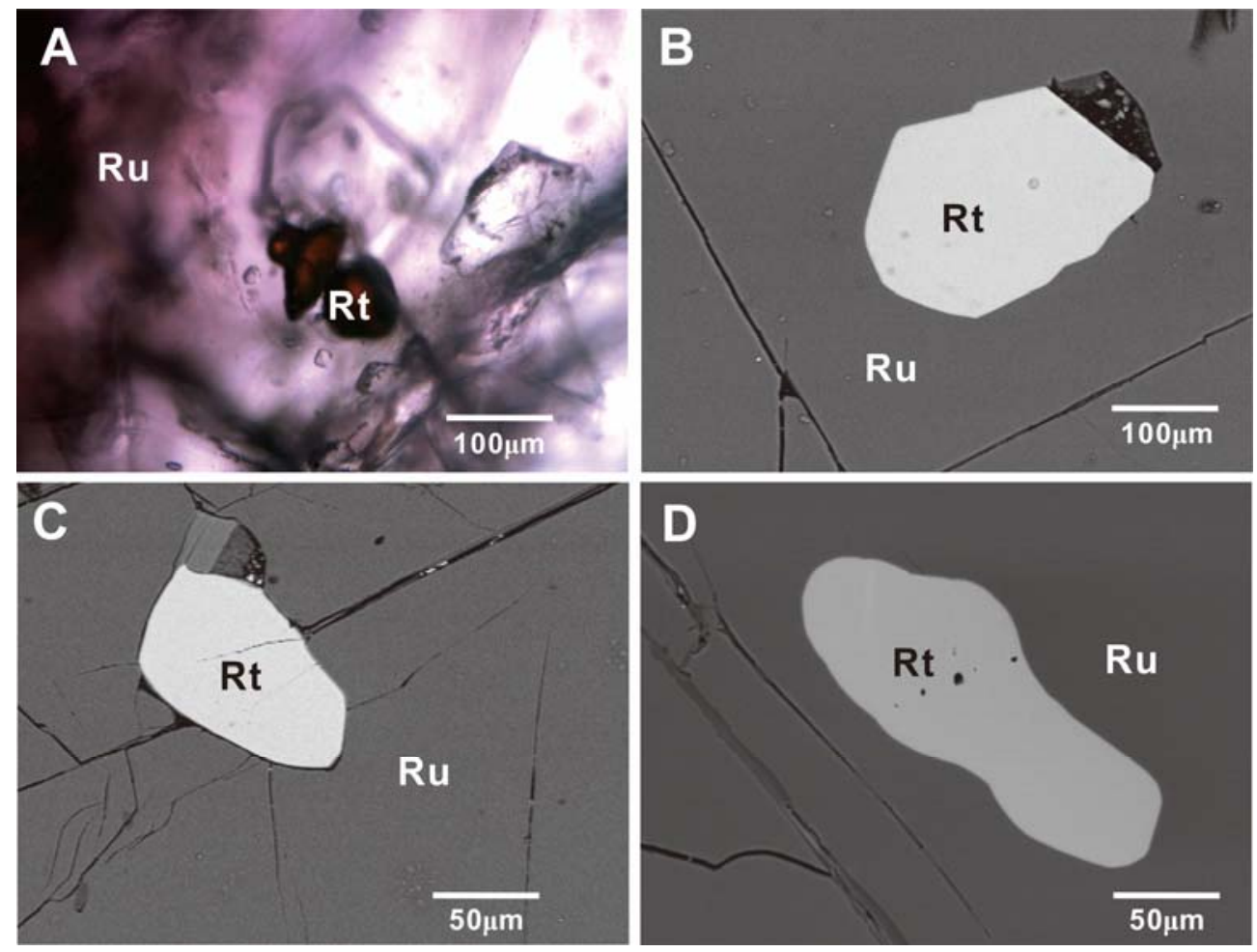

Figure 2. (A) Micrograph of rutile inclusions and (B-D) representative BSE images of rutile inclusions after polish to the surface of ruby. Abbreviations: Ru—ruby, Rt—rutile.

Raman spectroscopy of rutile inclusions was conducted by using Renishaw inVia confocal micro-Raman spectrometer at Instrumental Analysis and Research Center, Sun Yat-Sen University (SYSU). $\mathrm{Ar}^{+}$laser with $514.5 \mathrm{~nm}$ excitation was used and the Raman signals were collected over 50 to $2000 \mathrm{~cm}^{-1}$.

Rutile inclusions were carefully polished until it totally exposed on the surface of hosted ruby crystals for LA-ICP-MS analyses. Back-scattered electron images (BSE) of rutile inclusions were conducted by $\sum$ SIGMA scanning electron microscope (SEM) to check its inner structure at the School of Earth Sciences and Engineering, SYSU. The trace elements and $\mathrm{U}-\mathrm{Pb}$ isotopic composition analyses of rutile inclusions were conducted at the Key Laboratory of Marine Resources and Coastal Engineering, SYSU. 22 dated spots were conducted on 8 rutile inclusions from 8 selected ruby crystals. Calibration rutile reference material R10 ( $\sim 30 \mathrm{ppm} \mathrm{U}, 1090 \pm 5 \mathrm{Ma}$, [17]) was served as matrix-matched internal standard to calibrate the $\mathrm{U}-\mathrm{Pb}$ isotope fractionation of rutile inclusions [13], and the quality control material R19 yielded a concordant weighted average age of $493 \pm 8 \mathrm{Ma}(2 \sigma, M S W D$ $=0.2$ ) during analyses, which is in line with its thermal infrared mass spectrometry (TIMS) ${ }^{206} \mathrm{~Pb} /{ }^{238} \mathrm{U}$ age within the analytical uncertainties ( $\left.15 \mathrm{ppm} \mathrm{U}, 489.5 \pm 0.9 \mathrm{Ma},[16]\right)$. During $\mathrm{U}-\mathrm{Pb}$ dating, trace elements of rutile inclusions were simultaneously determined by monitoring ${ }^{24} \mathrm{Mg},{ }^{27} \mathrm{Al},{ }^{29} \mathrm{Si},{ }^{49} \mathrm{Ti},{ }^{51} \mathrm{~V},{ }^{53} \mathrm{Cr},{ }^{57} \mathrm{Fe},{ }^{60} \mathrm{Ni},{ }^{65} \mathrm{Cu},{ }^{89} \mathrm{Y},{ }^{90} \mathrm{Zr},{ }^{93} \mathrm{Nb},{ }^{95} \mathrm{Mo}$, ${ }^{118} \mathrm{Sn},{ }^{121} \mathrm{Sb},{ }^{178} \mathrm{Hf},{ }^{181} \mathrm{Ta},{ }^{232} \mathrm{Th},{ }^{238} \mathrm{U}$. The NIST SRM 610 was used as calibration materials, 
and ${ }^{49} \mathrm{Ti}$ was taken as an internal standard for unknown rutile after normalized $\mathrm{TiO}_{2}$ to $100 \%$ [13]. The averaged results of quality control material BCR-2G, rutile R10, and R19 are in concordance within 5\% reported values [16-18].

An ArF excimer laser ablation system with Ar-He stream transportation system attached to an Agilent $7700 \times$ ICP-MS was used to acquired ion-signal intensities. A $32 \mu \mathrm{m}$ spot is generally used with an energy density of $5 \mathrm{~J} / \mathrm{cm}^{2}$ and a repetition rate of $5 \mathrm{~Hz}$. Each analysis consists of $20 \mathrm{~s}$ background acquisition followed by $45 \mathrm{~s}$ sample analysis and $25 \mathrm{~s}$ washout. Off-line selection, integration of background and analyzed signals, time-drift correction, quantitative calibration for trace elemental analyses and $\mathrm{U}-\mathrm{Pb}$ isotopic results were conducted by ICPMSDataCal 10.2 software [19]. Concordia diagrams were performed using Isoplot3 software [20].

\section{Results}

\subsection{Raman Analyses of Rutile Inclusions}

Laser micro-Raman spectrum analyses are capable of separating the polymorphism of $\mathrm{TiO}_{2}$, which includes brookite, anatase, and rutile [14]. The spectroscopy of $\mathrm{TiO}_{2}$ in Yuanjiang ruby crystal is close to rutile standard spectrum diagram, which was characterized by the peak wavenumbers at $\sim 143, \sim 247, \sim 447$, and $\sim 612 \mathrm{~cm}^{-1}$ (Figure 3; [14,21,22]).

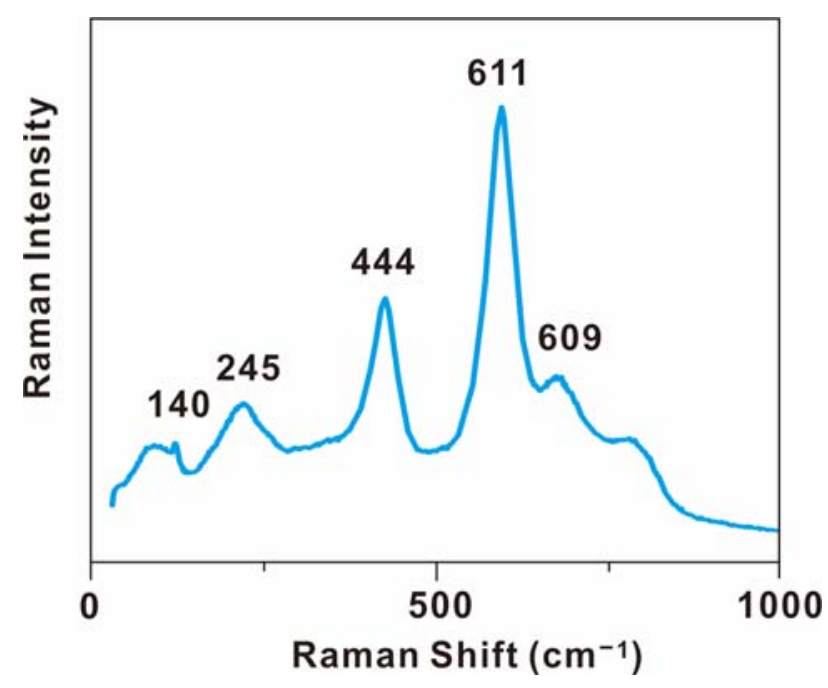

Figure 3. Representative Raman spectrum of rutile inclusion (Ru-1).

\subsection{Trace Elemental and U-Pb Dating Results of Rutile Inclusions}

Rutile inclusions in Yuanjiang ruby crystals are anhedral and oval shapes $(80-200 \mu \mathrm{m}$ in length and 50-100 $\mu \mathrm{m}$ in width), showing homogeneous structure without visible zoning and inherited cores in BSE images (Figure 2B-D).

LA-ICP-MS trace elemental contents data for rutile inclusions are listed in Table 1. These rutile inclusions contain relatively high $\mathrm{Cr}$ (1743-5362 ppm), Nb (2407-4759 ppm), $\mathrm{Zr}$ (887-3031 ppm), and V (3138-6693 ppm) contents, and relatively low abundance of Ta (44-713 ppm), Hf (45-263 ppm), W (15-552 ppm), Fe (11-114 ppm), Cu (4-68 ppm), Sn (7-124 ppm), Sb (0.1-1.9 ppm), Mo (<0.2ppm) contents.

The rutile inclusions show extremely low $T h(<2.5 \mathrm{ppm})$ and variable amounts of $\mathrm{U}$ (8.5-154.1 ppm), giving consistently low Th/U ratios $(<0.03)$. On the Tera-Wasserburg plot, the uncorrected $\mathrm{U}-\mathrm{Pb}$ data of 22 analyses form a well-defined regression line, giving a lower intercept ${ }^{206} \mathrm{~Pb} /{ }^{238} \mathrm{U}$ age of $20.2 \pm 1.2 \mathrm{Ma}$ and a Y-axis intercept (common ${ }^{207} \mathrm{~Pb} /{ }^{206} \mathrm{~Pb}$ ratio) of $0.705 \pm 0.085(M S W D=0.9)$ (Figure 4). 
Table 1. Trace element contents (ppm) of rutile inclusions in rubies, Yuanjiang ruby deposit area.

\begin{tabular}{|c|c|c|c|c|c|c|c|c|c|c|c|c|c|c|}
\hline Spot No. & Al & $\mathrm{Cr}$ & $\mathrm{Nb}$ & $\mathrm{Zr}$ & $\mathbf{V}$ & Ta & Hf & $\mathrm{Mg}$ & $\mathbf{W}$ & $\mathrm{Fe}$ & $\mathrm{Cu}$ & Sn & $\mathrm{Sb}$ & Mo \\
\hline $\mathrm{Ru}-1$ & 41 & 5362 & 3715 & 1026 & 3198 & 592 & 59 & 53 & 25 & 11 & 31 & 12 & 0.6 & 0.2 \\
\hline $\mathrm{Ru}-2$ & 4229 & 5277 & 3516 & 887 & 3138 & 440 & 45 & 60 & 15 & 23 & 28 & 7 & 0.5 & $\mathrm{Bdl}^{1}$ \\
\hline Ru-3 & 77 & 2353 & 3167 & 2708 & 4772 & 475 & 263 & 45 & 552 & 48 & 6 & 46 & 1.0 & 0.4 \\
\hline $\mathrm{Ru}-4$ & 76 & 3803 & 4041 & 3031 & 5098 & 550 & 154 & 45 & 31 & 18 & 6 & 40 & 0.3 & 0.3 \\
\hline Ru-5 & 73 & 3693 & 4053 & 2930 & 4991 & 505 & 145 & 45 & 27 & 16 & 5 & 37 & 0.1 & 0.1 \\
\hline Ru-6 & 68 & 3762 & 4214 & 2827 & 4856 & 545 & 134 & 42 & 26 & 67 & 6 & 38 & 0.3 & 0.2 \\
\hline $\mathrm{Ru}-7$ & 66 & 3901 & 4186 & 2956 & 5000 & 561 & 142 & 47 & 28 & 19 & 10 & 37 & 0.3 & 0.2 \\
\hline $\mathrm{Ru}-8$ & 59 & 3997 & 4454 & 2980 & 5007 & 658 & 145 & 42 & 35 & 19 & 7 & 37 & 0.3 & 0.4 \\
\hline $\mathrm{Ru}-9$ & 182 & 4186 & 4138 & 2295 & 5722 & 367 & 111 & 51 & 220 & 114 & 9 & 38 & 3.2 & 0.6 \\
\hline Ru-10 & 39 & 4329 & 4196 & 2306 & 5783 & 468 & 106 & 46 & 133 & 15 & 7 & 40 & 0.7 & 0.6 \\
\hline Ru-11 & 38 & 2395 & 3497 & 2153 & 4597 & 476 & 214 & 46 & 144 & 71 & 10 & 114 & 2.0 & 0.2 \\
\hline Ru-12 & 41 & 3704 & 4759 & 2036 & 6693 & 713 & 230 & 47 & 457 & 49 & 7 & 125 & 1.3 & $\mathrm{Bdl}^{1}$ \\
\hline Ru-13 & 77 & 2428 & 2980 & 2323 & 4382 & 288 & 218 & 42 & 188 & 72 & 6 & 50 & 1.2 & 0.3 \\
\hline Ru-14 & 95 & 2362 & 3049 & 2003 & 4497 & 291 & 160 & 48 & 200 & 48 & 6 & 48 & 1.0 & 1.0 \\
\hline Ru-15 & 240 & 2476 & 2952 & 2405 & 4378 & 248 & 256 & 54 & 176 & 61 & 8 & 47 & 1.7 & 0.4 \\
\hline Ru-16 & 61 & 2446 & 3001 & 2400 & 4279 & 257 & 255 & 46 & 183 & 58 & 8 & 42 & 1.1 & 0.6 \\
\hline Ru-17 & 205 & 2284 & 3161 & 1441 & 4560 & 331 & 74 & 41 & 252 & 87 & 7 & 61 & 1.7 & 2.2 \\
\hline Ru-18 & 3339 & 2074 & 2628 & 1990 & 4048 & 252 & 177 & 64 & 167 & 40 & 6 & 59 & 0.9 & 0.1 \\
\hline Ru-19 & 56 & 1995 & 2664 & 2131 & 4394 & 289 & 192 & 45 & 90 & 543 & 6 & 63 & 0.6 & $\mathrm{Bdl}^{1}$ \\
\hline Ru-20 & 87 & 1743 & 2657 & 2012 & 4575 & 323 & 174 & 60 & 97 & 68 & 6 & 60 & 1.1 & 0.2 \\
\hline Ru-21 & 108 & 2068 & 2558 & 2351 & 4555 & 336 & 203 & 48 & 145 & 63 & 68 & 55 & 0.9 & 0.4 \\
\hline Ru-22 & 84 & 2365 & 2407 & 2296 & 4476 & 303 & 231 & 46 & 137 & 88 & 4 & 48 & 0.7 & $\mathrm{Bdl}^{1}$ \\
\hline
\end{tabular}

Bdl means the testing value is below detection limit.

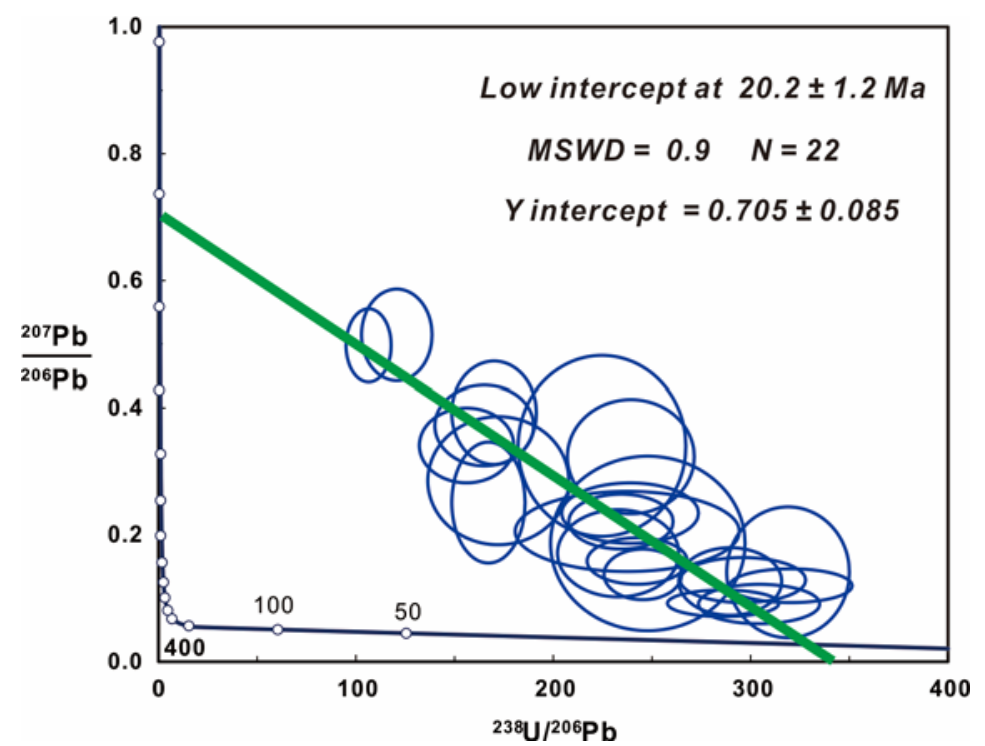

Figure 4. The Tera-Wasserburg plot of the uncorrected $\mathrm{U}-\mathrm{Pb}$ data of rutile inclusions.

\section{Discussion}

\subsection{The Relationship between Rutile and Ruby}

Rutile inclusions in Yuanjiang rubies are intact and maintain distance from fractures, meeting the criteria of syngenetic inclusions [5,23]. During LA-ICP-MS analyses, the occurrence of abnormal Al signal peak in the LA-ICP-MS time-resolved spectra (e.g., Ru-2, Ru-18; Table 1; Figure 5) with the unusually higher Al contents of rutile inclusions (Table 1) indicate that rubies $\left(\mathrm{Al}_{2} \mathrm{O}_{3}\right)$ also occasionally occur as inclusions in the rutile inclusions though not directly proved by petrographic observation, this mutual encapsulated relationship indicates that the rubies and rutiles syngenetically grew under the same conditions.

Geochemically, these rutile inclusions are distinguished by their high $\mathrm{V}, \mathrm{Nb}, \mathrm{Cr}, \mathrm{Zr}$ content (with the average of 4682 ppm, 3454 ppm, 3136 ppm, 2249 ppm, respectively) and low Fe (with the average of 73 ppm, Table 1) content compared with metamafic and metapelitic rutiles. These characters distinct our rutile inclusions from the more commonly reported metamafic and metapelitic rutiles (Figure 6; [14,24-27]). This difference can be 
attributed to that our rutile-rubies were crystalized from exceptional V-rich, Cr-rich and Fe-poor ruby-bearing carbonate protolith [28]. Moreover, the V, Cu, W, Sn, Sb contents (with the average of 12, 151, 50 and $1 \mathrm{ppm}$, respectively) of rutile inclusions are significantly lower than those of hydrothermal rutile [22,29], which suggest that rutile inclusions were protected by their host ruby from the physical interference of later hydrothermal fluids. Thus, the syngenetic, high $\mathrm{U}$, undisturbed rutile inclusions have great potentials to provide more constraints on the timing of ruby growth in the Yuanjiang area [13].

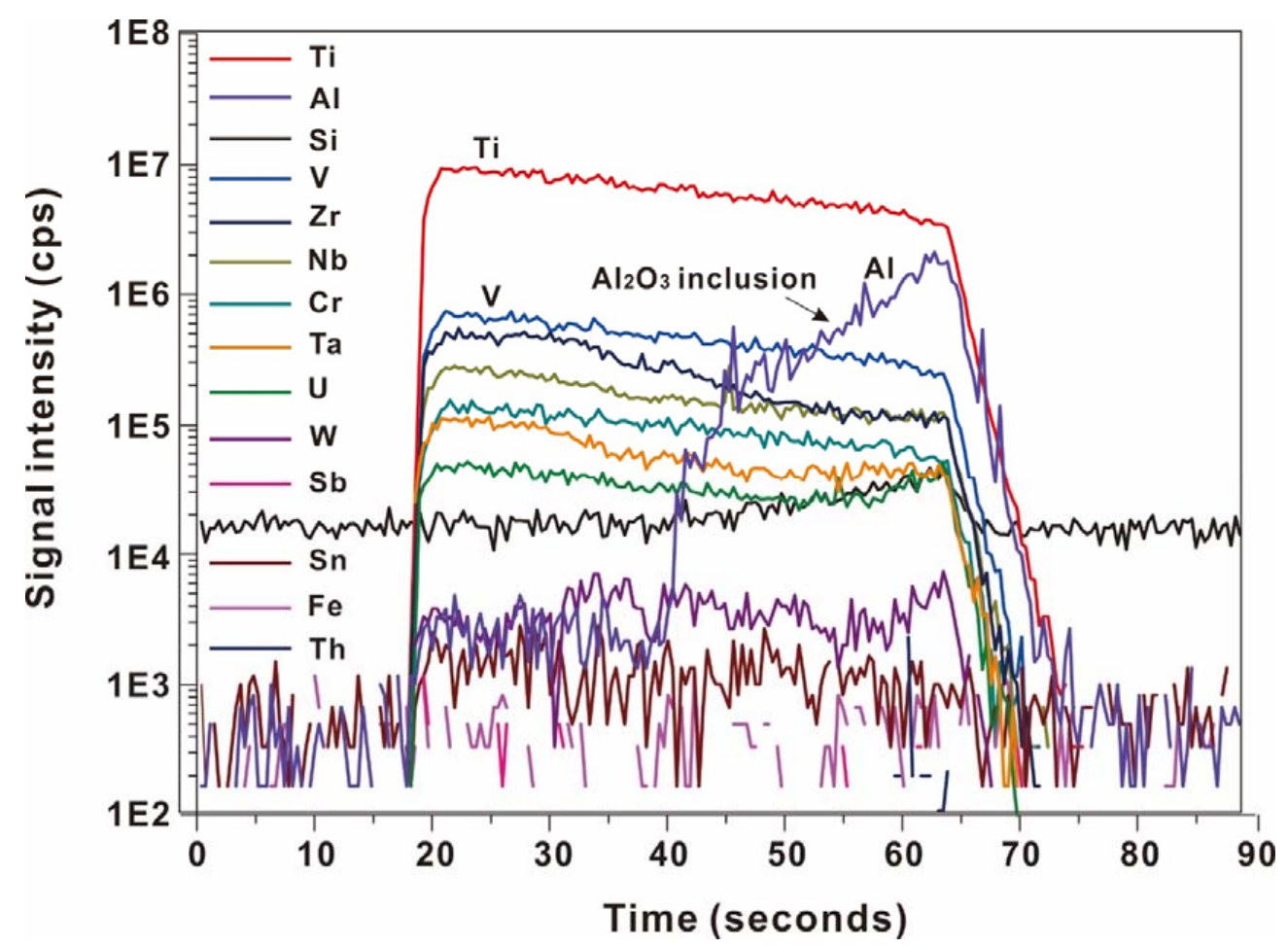

Figure 5. Time-resolved raw signal of rutile inclusion ablation signals (Ru-2).

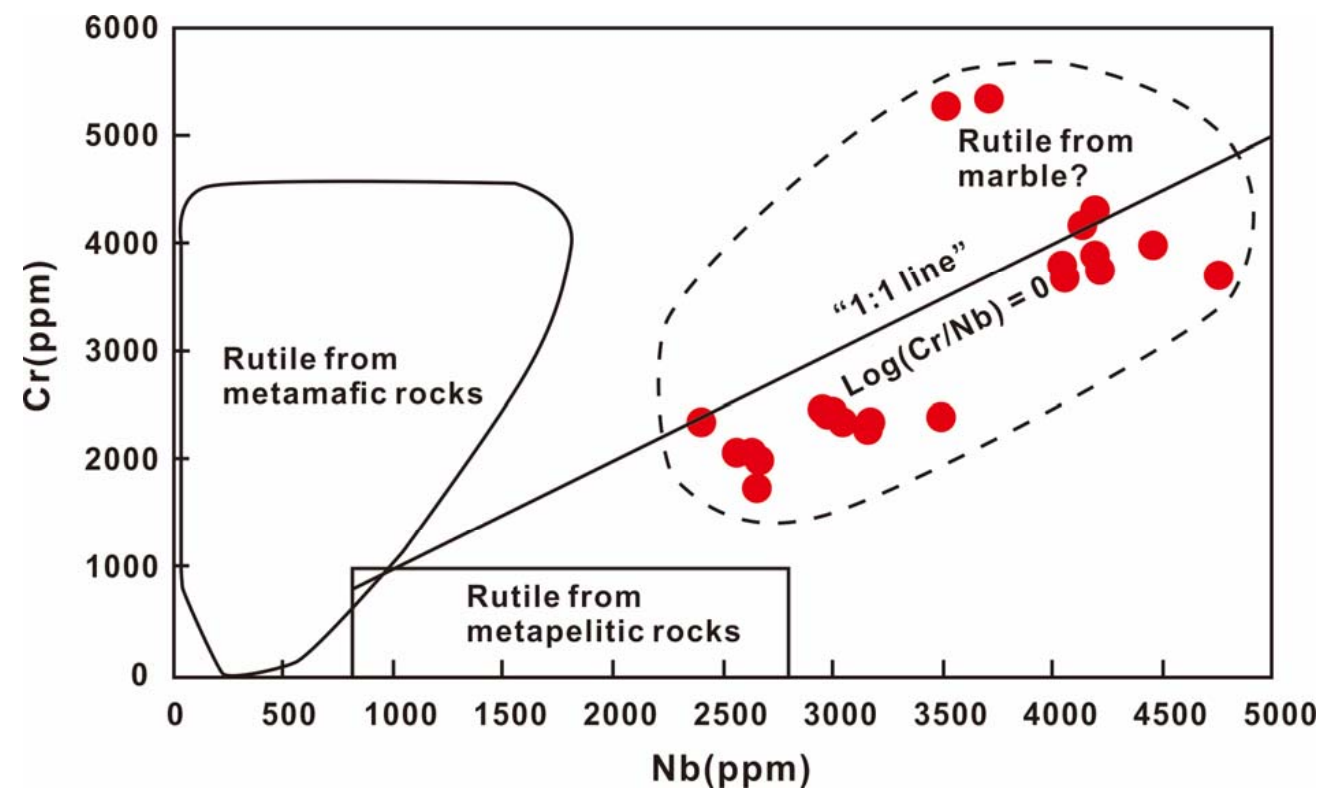

Figure 6. $\mathrm{Cr}-\mathrm{Nb}$ discrimination diagrams of rutile inclusions. Fields of metamafic and metapelitic rutile are from $[25,26]$. $\log (\mathrm{Cr} / \mathrm{Nb})=0$ according to [27]. 


\subsection{Interpretation of Rutile Inclusion $\mathrm{U}-\mathrm{Pb}$ Dating Results}

Our results reveal that rutile inclusions contain high $\mathrm{U}$ (with the average of $62 \mathrm{ppm}$ Table 2). Given the most of dating data are far away from the $\mathrm{Y}$-axis $\left({ }^{207} \mathrm{~Pb} /{ }^{206} \mathrm{~Pb}\right)$, the lower intercept of $20.2 \pm 1.2 \mathrm{Ma}$ on the discordia can be taken as reliable age of rutile inclusions (Figure 4, [30]).

Table 2. LA-ICP-MS U-Pb results of rutile inclusion in ruby, Yuanjiang ruby deposit area.

\begin{tabular}{|c|c|c|c|c|c|c|c|c|}
\hline \multirow{2}{*}{ Spot No. } & \multirow{2}{*}{$\begin{array}{c}\text { Th } \\
\text { ppm }\end{array}$} & \multirow{2}{*}{$\frac{\mathrm{U}}{\mathrm{ppm}}$} & \multicolumn{6}{|c|}{ Measured Isotope Ratios } \\
\hline & & & ${ }^{207} \mathrm{~Pb} /{ }^{206} \mathrm{~Pb}$ & 1sigma & ${ }^{207} \mathrm{~Pb} /{ }^{235} \mathrm{U}$ & 1sigma & ${ }^{206} \mathrm{~Pb} /{ }^{238} \mathrm{U}$ & 1sigma \\
\hline $\mathrm{Ru}-1$ & 0.1 & 21 & 0.3483 & 0.0817 & 0.3169 & 0.0506 & 0.0059 & 0.0005 \\
\hline $\mathrm{Ru}-2$ & 0.0 & 25 & 0.5539 & 0.0856 & 0.6413 & 0.0672 & 0.0094 & 0.0007 \\
\hline $\mathrm{Ru}-3$ & 0.0 & 43 & 0.1809 & 0.0478 & 0.1012 & 0.0283 & 0.0043 & 0.0004 \\
\hline $\mathrm{Ru}-4$ & 0.0 & 102 & 0.1423 & 0.0372 & 0.0608 & 0.0297 & 0.0031 & 0.0002 \\
\hline $\mathrm{Ru}-5$ & 0.0 & 101 & 0.1293 & 0.0274 & 0.0597 & 0.0173 & 0.0035 & 0.0002 \\
\hline $\mathrm{Ru}-6$ & 0.0 & 97 & 0.0989 & 0.0184 & 0.0441 & 0.0070 & 0.0035 & 0.0002 \\
\hline $\mathrm{Ru}-7$ & 0.0 & 99 & 0.1469 & 0.0331 & 0.0510 & 0.0083 & 0.0031 & 0.0002 \\
\hline $\mathrm{Ru}-8$ & 0.0 & 103 & 0.2616 & 0.1179 & 0.0769 & 0.0151 & 0.0041 & 0.0002 \\
\hline $\mathrm{Ru}-9$ & 2.0 & 120 & 0.2476 & 0.0687 & 0.0895 & 0.0150 & 0.0041 & 0.0003 \\
\hline Ru-10 & 0.2 & 122 & 0.1796 & 0.0709 & 0.0408 & 0.0098 & 0.0033 & 0.0002 \\
\hline Ru-11 & 0.1 & 9 & 0.1346 & 0.0773 & 0.2280 & 0.0620 & 0.0058 & 0.0008 \\
\hline Ru-12 & 0.6 & 19 & 0.0532 & 0.0241 & 0.1032 & 0.0524 & 0.0040 & 0.0005 \\
\hline Ru-13 & 0.2 & 38 & 0.3455 & 0.0798 & 0.1345 & 0.0222 & 0.0042 & 0.0004 \\
\hline Ru-14 & 0.1 & 61 & 0.2629 & 0.0494 & 0.1300 & 0.0194 & 0.0043 & 0.0003 \\
\hline Ru-15 & 0.1 & 30 & 0.2356 & 0.0753 & 0.1856 & 0.0380 & 0.0042 & 0.0004 \\
\hline Ru-16 & 0.0 & 29 & 0.2366 & 0.0790 & 0.2084 & 0.0633 & 0.0045 & 0.0006 \\
\hline Ru-17 & 2.5 & 96 & 0.3802 & 0.0704 & 0.3002 & 0.0455 & 0.0064 & 0.0006 \\
\hline Ru-18 & 1.8 & 154 & 0.1832 & 0.0489 & 0.0597 & 0.0119 & 0.0034 & 0.0002 \\
\hline Ru-19 & 0.0 & 19 & 0.0866 & 0.0322 & 0.1188 & 0.0309 & 0.0042 & 0.0007 \\
\hline Ru-20 & 0.0 & 20 & 0.2753 & 0.0675 & 0.3103 & 0.0467 & 0.0061 & 0.0006 \\
\hline $\mathrm{Ru}-21$ & 0.6 & 22 & 0.1997 & 0.0616 & 0.2072 & 0.0541 & 0.0060 & 0.0004 \\
\hline $\mathrm{Ru}-22$ & 0.4 & 21 & 0.5463 & 0.0866 & 0.5879 & 0.0786 & 0.0083 & 0.0008 \\
\hline
\end{tabular}

The marked gap between the U-Pb age of rutile $(20.2 \pm 1.2 \mathrm{Ma})$ and zircon inclusions (36.2 $\pm 1.1 \mathrm{Ma}$, [5]) suggests that the 'armoring effect' of rutile inclusions by the hosted rubies has been ineffective, consistent with the reported ineffective garnet 'shielding' on rutile inclusions under multi-thermal conditions in North Dabie eclogite [31]. Considering that the $\mathrm{Pb}$ diffusion rate of rutile is significantly faster than that of zircon, the new obtained ${ }^{206} \mathrm{~Pb} /{ }^{238} \mathrm{U} 20.2 \pm 1.2 \mathrm{Ma}$ age of rutile inclusions, which falls close to the range of ${ }^{40} \mathrm{Ar}-{ }^{39} \mathrm{Ar}$ ages of phlogopite at 22.5-22.2 Ma [5], is interpreted as the cooling age of the Yuanjiang ruby deposit.

\subsection{The Spatial-Temporal Relationship of the Ruby Mineralization and Tectonic Evolution}

The widespread distribution of multi-stage foliation, mylonitic rocks, migmatites, leucocratic dikes indicate the complicated Oligocene-Miocene tectonic evolution of the Ailao Shan-Red River shear zone in response to progressive India-Eurasia collision. The $\mathrm{U}-\mathrm{Pb}$ dating of monazite and zircon inclusions in the pre-shearing corundum as well as zircons from the syn-kinematic leucocratic dikes indicate that the initiation of the largescale left lateral shearing is around $\sim 28 \mathrm{Ma}[32,33]$. Zircon inclusions in the rubies were dated at 36.2 and 38.1 Ma for the Yuanjiang deposit [5] and the Luc-Yen deposit [7,34], respectively, suggesting that the trigger of the marble-hosted ruby mineralization was prior to the left lateral shearing and coeval with the local crustal thickening related continental subduction-collision [5]. The obtained ${ }^{206} \mathrm{~Pb} /{ }^{238} \mathrm{U}$ age of rutile inclusions in Yuanjiang rubies, $20.2 \pm 1.2 \mathrm{Ma}$, is approximate to the range of phlogopite ${ }^{40} \mathrm{Ar}-{ }^{39} \mathrm{Ar}$ ages of Yuanjiang deposit (22.5-22.2 Ma) [5] and Yen Bai deposit (24.4-23.2 Ma) [7], collectively reflecting that the left lateral shearing plays an important role in transporting ruby deposit toward the surface [5]. 


\section{Conclusions}

Rutile inclusions in Yuanjiang rubies possess the characteristic of high $\mathrm{V}, \mathrm{Nb}, \mathrm{Cr}$, $\mathrm{Zr}$ and low Fe content, which clearly discriminated our rubies-hosted rutile inclusions from the metamafic, metapelitic and hydrothermal rutile. In-situ LA-ICP-MS U-Pb dating of rutile inclusions in the Yuanjiang rubies, which yielded a reliable ${ }^{206} \mathrm{~Pb} /{ }^{238} \mathrm{U}$ age of $20.2 \pm 1.2 \mathrm{Ma}$, is approximate to the ${ }^{40} \mathrm{Ar}-{ }^{39} \mathrm{Ar}$ ages of phlogopite, helps to constrain the cooling age of Yuanjiang ruby deposit. Our study provides the first example of LA-ICP-MS $\mathrm{U}-\mathrm{Pb}$ dating of rutile in the Himalayan tectonic belt, suggesting that $\mathrm{U}-\mathrm{Pb}$ dating of rutile is a geochronological tool of great potential for young Cenozoic deposits.

Author Contributions: T.Y. and X.S. conceived and designed the experiments; T.Y., Y.L., G.S. and T.Y. did sample preparation and analyzed the data; T.Y. wrote the manuscript; X.S. substantially revised the original manuscript. All authors have read and agreed to the published version of the manuscript.

Funding: This research was funded by the National Natural Science Foundation of China (91855213, 41672071, U1302233) and the National Key Research and Development Program of China (2018YFA0702605).

Institutional Review Board Statement: Not Applicable.

Informed Consent Statement: Not Applicable.

Data Availability Statement: Data is contained within the article.

Acknowledgments: We appreciate Weihong Zhang (Instrumental analysis and research center, Sun Yat-sen University) for their help during Raman analyses. Xiaoping Xia is thanked for kindly providing the rutile reference material R10 and R19. This manuscript greatly benefited from the valuable comments and suggestions from four anonymous reviewers, Frederick Lin Sutherland and Academic Editor of Minerals.

Conflicts of Interest: The authors declare no conflict of interest.

\section{References}

1. Garnier, V.; Giuliani, G.; Ohnenstetter, D.; Fallick, A.E.; Dubessy, J.; Banks, D.; Vinh, H.Q.; Lhomme, T.; Maluski, H.; Pêcher, A.; et al. Marble-hosted ruby deposits from Central and Southeast Asia: Towards a new genetic model. Ore Geol. Rev. 2008, 34, 169-191. [CrossRef]

2. Stern, B.; Tsujimori, T.; Harlow, G.; Groat, L.A. Plate tectonic gemstones. Geology 2013, 41, 723-726. [CrossRef]

3. Qian, T.H.; Yao, S.Z.; Wang, Y.Z. The geological features and meaning of ruby deposit in Ailaoshan, Yunnan Province. Miner. Depos. 1996, 15, 29-30. (In Chinese)

4. Zhang, J.F.; Zhou, C.H.; Hu, C.S. Mineralization characteristics of gems in Ailaoshan structural belt, Yunnan Province. J. Gems. Gem. 2003, 5, 27-30, (In Chinese with English abstract).

5. Yang, T.J.; Sun, X.M.; Shi, G.Y.; Li, D.S.; Zhou, H.Y. The genetic linkage between the Yuanjiang marble-hosted ruby deposit and Cenozoic tectonic evolution of the Ailao Shan-Red River shear zone (Southwest China). J. Asian Earth Sci. 2019, 177, 38-47. [CrossRef]

6. Harrison, T.M.; Celerier, J.; Aikman, A.B.; Hermann, J.; Heizler, M.T. Diffusion of ${ }^{40}$ Ar in muscovite. Geochim. Cosmochim. Acta 2009, 73, 1039-1051. [CrossRef]

7. Garnier, V.; Giuliani, G.; Maluski, H.; Ohnenstetter, D.; Trong, T.P.; Quang, V.H.; Van, L.P.; Van, T.V.; Schwarz, D. Ar-Ar ages in phlogopites from marble-hosted ruby deposits in northern Vietnam: Evidence for Cenozoic ruby formation. Chem. Geol. 2002, 188, 33-49. [CrossRef]

8. Coenraads, R.R.; Sutherland, F.L.; Kinny, P.D. The origin of sapphires: U-Pb dating of zircon inclusions sheds new light. Mineral. Mag. 1990, 54, 113-122. [CrossRef]

9. Coenraads, R.R.; Vichit, P.; Sutherland, F.L. An unusual sapphire-zircon-magnetite xenolith from the Chanthaburi Gem Province. Minear. Mag. 1995, 59, 465-479. [CrossRef]

10. Sutherland, F.L.; Bosshart, G.; Fanning, C.M.; Hoskin, P.W.O.; Coenraads, R.R. Sapphire crystallization, age and origin, Ban Huai Sai, Laos: Age based on zircon inclusions. J. Asian Earth Sci. 2002, 20, 841-849. [CrossRef]

11. Sutherland, F.L.; Duroc-Danner, J.M.; Meffre, S. Age and origin of gem corundum and zircon megacrysts from the Mercaderes-Rio Mayo area, South-west Colombia, South America. Ore Geol. Rev. 2008, 34, 155-168. [CrossRef]

12. Graham, I.; Sutherland, L.; Zaw, K.; Nechaev, V.; Khanchuk, A. Advances in our understanding of the gem corundum deposits of the West Pacific continental margins intraplate basaltic fields. Ore Geol. Rev. 2008, 34, 200-215. [CrossRef]

13. Sorokina, E.S.; Rösel, D.; Häger, T.; Mertz-Kraus, R.; Saul, J.M. LA-ICP-MS U-Pb dating of rutile inclusions within corundum (ruby and sapphire): New constraints on the formation of corundum deposits along the Mozambique belt. Miner. Depos. 2017, 52, 1-9. [CrossRef] 
14. Meinhold, G. Rutile and its applications in earth sciences. Earth Sci. Rev. 2010, 102, 1-28. [CrossRef]

15. Cherniak, D.J. Pb diffusion in rutile. Contrib. Miner. Petrol. 2000, 139, 198-207. [CrossRef]

16. Zack, T.; Stockli, D.F.; Luvizotto, G.L.; Barth, M.G.; Belousova, E.; Wolfe, M.R.; Hinton, R.W. In situ U-Pb rutile dating by LA-ICP-MS: ${ }^{208} \mathrm{~Pb}$ correction and prospects for geological applications. Contrib. Miner. Petrol. 2011, 162, 515-530. [CrossRef]

17. Luvinzotto, G.L.; Zack, T. Nb and Zr behavior in rutile during high-grade metamorphism and retrogression: An example from the Ivrea-Verbano Zone. Chem. Geol. 2009, 261, 303-317. [CrossRef]

18. Jochum, K.P.; Weis, U.; Schwager, B.; Stoll, B.; Wilson, S.A.; Haug, G.H.; Andreae, M.O.; Enzweiler, J. Reference values following ISO guidelines for frequently requested rock reference materials. Geostand. Geoanal. Res. 2016, 40, 333-350. [CrossRef]

19. Liu, Y.S.; Gao, S.; Hu, Z.C.; Gao, C.G.; Zong, K.Q.; Wang, D.B. Continental and oceanic crust recycling-induced melt-peridotite interactions in the Trans-North China orogen: U-Pb dating, Hf isotopes and trace elements in zircons from mantle xenoliths. J. Petrol. 2010, 51, 537-571. [CrossRef]

20. Ludwig, K.R. User's Manual for Isoplot 3.0: A Geochronological Toolkit for Microsoft Excel; Special Publication; Berkeley Geochronology Center: Berkeley, CA, USA, 2003; pp. 1-70.

21. He, M.C.; Zhu, X.M.; Hong, B. Raman spectrum feature of ruby from Yuanjiang, Yunnan Province. J. Gems. Gem. 2001, 3, 25-27, (In Chinese with the English abstract).

22. Pi, Q.H.; Hu, R.Z.; Xiong, B.; Li, Q.L.; Zhong, R.C. In situ SIMS U-Pb dating of hydrothermal rutile: Reliable age for the Zhesang Carlin-type gold deposit in the golden triangle region, SW China. Miner. Depos. 2017, 52, 1179-1190. [CrossRef]

23. Gubelin, E.J.; Koivula, J.I. Photoatlas of Inclusion in Gemstone; Gemological Institute of America: Zürich, Switzerland, 1986.

24. Zack, T.; Kronz, A.; Foley, S.F.; Rivers, T. Trace element abundances in rutiles from eclogites and associated garnet mica schists. Chem. Geol. 2002, 184, 97-122. [CrossRef]

25. Zack, T.; Moraes, R.; Kronz, A. Temperature dependence of Zr in rutile: Empirical calibration of a rutile thermometer. Contrib. Mineral. Petrol. 2004, 148, 471-488. [CrossRef]

26. Meinhold, G.; Anders, B.; Kostopoulos, D.; Reischmann, T. Rutile chemistry and thermometry as provenance indicator: An example from Chios Island, Greece. Sediment. Geol. 2008, 203, 98-111. [CrossRef]

27. Agangi, A.; Plavsa, D.; Reddy, S.M.; Oliver, H.; Kylander-Clark, A. Compositional modification and trace element decoupling in rutile: Insight from the Capricorn Orogen, Western Australia. Precambrian Res. 2020, 345, 105772. [CrossRef]

28. Pêcher, A.; Giuliani, G.; Garnier, V.; Maluski, H.; Kausar, A.B.; Malik, R.H.; Muntaz, H.R. Geology, geochemistry and Ar-Ar geochronology of the Nangimali ruby deposit, Nanga Parbat Himalaya (Azad Kashmir, Pakistan). J. Asian Earth Sci. 2002, 21, 265-282. [CrossRef]

29. Oliver, H.K.H.; Agangi, A.; Plavsa, D.; Reddy, S.M.; Yao, W.H.; Clark, C.; Occhipinti, S.A.; Kylander-Clark, A.R.C. Neoproterozoic hydrothermal activity in the West Australian Craton related to Rodinia assembly or breakup? Gondwana Res. 2019, 68, 1-12.

30. Oliver, H.K.H.; Taylor, R.J.M.; Erickson, T.M.; Clark, C.; Reddy, S.M.; Kirkland, C.L.; Jahn, I.; Barham, M. Unravelling complex geologic histories using $\mathrm{U}-\mathrm{Pb}$ and trace element systematics of titanite. Chem. Geol. 2019, 504, 105-122.

31. Zhou, T.; Li, Q.L.; Klemd, R.; Shi, Y.H.; Tang, X.; Li, C.F.; Liu, Y. Multi-system geochronology in North Dabie eclogite: Ineffective garnet 'shielding' on rutile inclusions under multi-thermal conditions. Lithos 2020, 368-369, 105573. [CrossRef]

32. Liu, J.L.; Chen, X.Y.; Tang, Y.; Song, Z.J.; Wang, W. The Ailao Shan-Red River shear zone revisited: Timing and tectonic implications. Geol. Soc. Am. Bull. 2019, 132, 5-6. [CrossRef]

33. Yang, T.J.; Sun, X.M.; Shi, G.Y.; Lu, Y.; Fu, Y. Constraints on the left lateral shearing and crustal melting of the Ailaoshan Massif, Yunnan Province, Southwest China. J. Asian Earth Sci. 2019, 177, 186-197. [CrossRef]

34. Garnier, V.; Ohnenstetter, D.; Giuliani, G.; Maluski, H.; Deloule, E.; Phan Trong, T.; PhamVan, L.; Hoang Quang, V. Age and significance of ruby-bearing marbles from the Red River shear zone, northern Vietnam. Can. Miner. 2005, 43, 1315-1329. [CrossRef] 